\title{
PEMETAAN WILAYAH RAWAN BAHAYA BANJIR DI KABUPATEN PAMEKASAN BERBASIS SISTEM INFORMASI GEOGRAFIS (SIG)
}

\author{
Anwari $^{1)}$, Masdukil Makruf ${ }^{2}$ \\ 1), 2) Program Studi Sistem Informasi, Fakultas Teknik, Universitas Islam Madura \\ Jl. PP. Miftahul Ulum Bettet Pamekasan \\ Email :anwari.uim@gmail.com ${ }^{1)}$,Masdukil.makruf@gmail.com ${ }^{2)}$
}

\begin{abstract}
Abstrak
Kabupaten Pamekasan merupakan salah satu kabupaten Propinsi Jawa Timur. Terletak di Pulau Madura, Kabupaten Pamekasan termasuk daerah yang sering dilanda banjir. menyebabkan kawasan selatan perkotaan Pamekasan dilanda banjir dengan ketinggian genangan air di rumah-rumah warga antara $1 m$ hingga 3m, bahkan ada sebagian wilayah yang mencapai lima meter. Salah satu cara peneliti untuk dapat mengelola wilayah rawan bahaya banjir adalah mengabungkan beberapa variabel diantaranya peta ketinggian wilayah (DEM), kelerengan, jenis tanah, penggunaan lahan, curah hujan. Menggunakan metode skoring, dan menghasilkan data spasial berupa daerah Potensi bahaya banjir. Dari hasil analisa didapat bahwa daerah Rawan Bajir dengan tingkat potensi tinggi berada pada daerah yang relatif datar dengan kemiringan $0-4 \%$ dan potensi daerah Rawan Banjir berada pada lahan dengan penggunaan yang paling banyak permukiman mencapai 341240,721(Ha). Selain itu curah hujan tahun 2013, curah hujan Pamekasan, dengan akumulasi rata-rata,421 mm/tahun. Daerah Rawan Banjir tingkat tinggi sebagian besar ketinggian 8-44,5 meter dan Jenis tanah juga merupakan penentu daerah Rawan Banjir, daerah Rawan Banjir tinggi didominasi jenis tanah Alluvial Hidromorf. Daerah Rawan Banjir berada pada Kecamatan Pamekasan, Pademawu, Galis. Penelitian Menunjukkan Ketinggian Banjir, Tinggi 6,75 - 9 sedang 6,75 - 4,5 rendah 4,5 - 2,25 tidak rawan 2,25.
\end{abstract}

Kata Kunci : Wilayah Rawan Bahaya Banjir, DEM, TRMM, SIG

\begin{abstract}
Pamekasan Regency is one of the districts in East Java Province. Located on Madura island, Pamekasan Regency is an area that is often flooded that caused Pamekasan's southern urban area get flooded with high water levels in residents' homes between $1 M$ and $3 M$, and even some areas that reached five meters. One way researchers can manage flood-prone areas is combining several variables including map of height (DEM), slope, soil type, land use, rainfall. Using scoring methods, and generate spatial data potential flood hazard areas. From the analysis resultsfound that the area of Rawan Banjir with high potential level is in a relatively flat area with a slope of 0 - $4 \%$ and the potential of the Flood Prone area is on land with the most use of settlements reaching 341240.721 (Ha). In addition to the 2013 rainfall, Pamekasan rainfall, with an average accumulation, $421 \mathrm{~mm} /$ year. High level Flood Prone Areas are mostly 8 - 44.5 meters high. and The type of soil is also a determinant of the Flood Prone area, the high flood hazard area is dominated by Alluvial Hydromorphic soil type. Banjir Prone Areas are in Pamekasan District, Pademawu, Galis. Research Shows Flood Height, Height 6.75 - 9 moderate 6.75 - 4.5 low 4.5 - 2.25 not susceptible to 2.25 .
\end{abstract}

Keywords : Flood-prone areas, DEM, TRMM, GIS

\section{PENDAHULUAN}

Bencana banjir telah menjadi persoalan bagi manusia di seluruh dunia, bencana ini bisa merupakan akibat dari peristiwa alam, aktifitas dan kegiatan manusia. Di Indonesia, terjadinya banjir dan besarannya bervariasi, hampir semua daerah menghadapi bahaya banjir yang signifikan. Kerugian dan kerusakan akibat banjir adalah sebesar dua pertiga dari semua bencana alam yang terjadi [1]. Setiap tahun lebih dari 300 peristiwa banjir terjadi di Indonesia yang menggenangi 150.000 ha dan merugikan sekitar 1.000 .000 orang. Saat ini kecenderungan bahaya banjir terus meningkat baik di perkotaan maupun pedesaan.

Permasalahan banjir yang terjadi setiap tahun di kabupaten Pamekasan karena luapan sungai yang tidak bisa menampung debit air kiriman dari wilayah utara, disebabkan jumlah aliran yang masuk ke kota Pamekasan sangat besar sehingga terjadi akumulasi aliran yang sangat tinggi. Faktor umum terjadinya 
banjir, dapat diketahui dari penebangan yang tidak terkontrol di daerah perbukitan, dan kesadaran masyarakat akan pentingnya untuk tidak membuang sampah sembarangan di belantaran sungai sehingga mengakibatkan sedimentasi yang sangat tinggi, juga dipersempit dengan rapatnya bangunan sehingga membuat permasalahan kompleks. Beberapa permasalah tersebut, akhirnya dapat memicu terjadinya banjir di pamekasan. Berdasarkan permasalahan tersebut perlu adanya penelitian tentang pemetaan wilayah rawan dan bahaya banjir di kabupaten Pamekasan.

Dari penjelasan di atas peneliti ingin melakukan pemodelan bahaya banjir untuk mengetahui volume banjir dan cakupan wilayah banjir dengan menggunakan data DEM SRTM, DAS, TRMM, Penggunaan Lahan, Jenis Tanah dan dilakukan overlay dari beberapa data tersebut untuk melihat dan menganalisis secara komprehensif wilayah kajian, sehingga penyebab utama banjir dapat diketahui. Data ini juga dapat digunakan sebagai masukkan dalam pemodelan daerah bahaya Banjir. Penelitian bertujuan untuk pembuatan model bahaya banjir dengan mengetahui penyebab utama banjir diwilayah kajian, serta pembuatan peta bahaya banjir di kebupaten pamekasan.

\section{DASAR TEORI}

\subsection{Metode Scoring}

Metode yang digunakan dalam penelitian ini, untuk penentuan daerah potensi genangan adalah metode scoring. Metode scoring dilakukan dengan pembobotan dan pemberian skor. Pemberian bobot dan skor tersebut dilakukan dengan mempertimbangkan tingkat pengaruh terhadap genangan [2]. Pembobotan adalah pemberian bobot pada masing masing parameter yang berpengaruh terhadap genangan, dengan didasarkan atas pertimbangan pengaruh masing-masing parameter terhadap genangan. Sedangkan pemberian skor merupakan proses pemberian skor pada sub variabel dari masing masing variabel.

\subsection{Tropical Rainfall Measuring Mission (TRMM)}

Tropical Rainfall Measuring Mission (TRMM) merupakan proyek kerjasama dua badan antariksa nasional milik Amerika Serikat (NASA : National Aeronautics and Space Administration) dan Jepang (NASDA : National Space Development Agency of Japan, sekarang berubah menjadi JAXA : Japan Aerospace Exploration Agency). TRMM dirancang untuk mengukur curah hujan (Precipitation) di daerah tropis beserta variasinya.

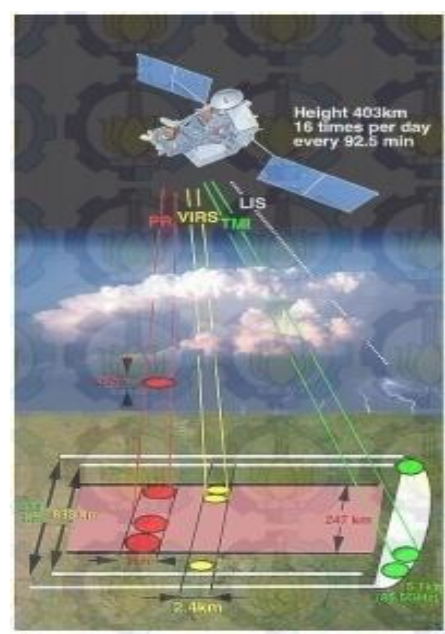

Gambar 1. Satelit TRMM dan Geometri Pemindaian Radar Hujan

Pada saat awal diluncurkan, TRMM memiliki ketinggian orbit hingga $350 \mathrm{~km}$, kemudian diubah ketinggian orbitnya menjadi $403 \mathrm{~km}$ sejak 24 Agustus 2001. Pengoperasian satelit TRMM pada ketinggian orbit $403 \mathrm{~km}$ ini dikenal dengan istilah TRMM boost. Satelit ini mengitari bumi sebanyak 16 kali per hari, setiap 92,5 menit. Sudut inklinasi satelit TRMM mencapai $35^{\circ}$ terhadap ekuator. Inklinasi adalah sudut antara bidang yang menjadi acuan dengan bidang yang diukur kemiringannya [3]. 


\subsection{SRTM (Shuttle Radar Topography Mission)}

Citra pengendaraan jauh SRTM (Shuttle Radar Topography Mission) merupakan salah satu jenis citra yang mempunyai kegunaan dalam analisis model elevasi. SRTM menggunakan teknologi SAR (Synhentic Apeture Radar). SRTM memiliki struktur data yang sama seperti format grid, yaitu terdiri dari sel-sel yang setiap sel memiliki nilai ketinggian. Nilai ketinggian pada SRTM dan DEM30 adalah nilai ketinggian dari datum WGS84 dan analisa citra DEM 30m yang digunakan untuk mengetahui akumulasi pola aliran permukaannya, baik pola aliran sungai, pola aliran kelurusan dan formasi batuan [4]. Shuttle Radar Topography Mission (SRTM) memperoleh data elevasi mendekati skala global yang paling lengkap untuk menghasilkan basis data resolusi tinggi topografi digital bumi.SRTM terdiri dari sistem radar modifikasi khusus yang terbang pada Space Shuttle Endevour selama 11 hari di bulan Februari pada tahun 2000.

\subsection{Digital Elevation Model}

Digital Elevation Model (DEM) merupakan salah satu model untuk menggambarkan bentuk topografi permukaan bumi sehingga dapat divisualisasikan kedalam tampilan 3D (tiga dimensi). Ada banyak cara untuk memperoleh data DEM, interferometri SAR (Synthetic Aperture Radar) merupakan salah satu algoritma untuk membuat data DEM. Data citra SAR atau citra radar yang digunakan dalam proses interferometri dapat diperoleh dari wahana satelit atau pesawat [5]. Dalam penelitian ini, DEM digunakan untuk pembuatan peta ketinggian wilayah dan peta kelerengan yang berfungsi sebagai parameter dalam penentuan daerah potensi genangan. Kedua parameter tersebut sangat penting mengingat prinsip air yang mengalir dari tempat yang tinggi ke tempat yang rendah, maka semakin datar dan rendah suatu kawasan, semakin berpotensi genangan kawasan tersebut.

\subsection{Sistem Informasi Geografis (SIG)}

\subsubsection{Pengertian SIG}

Definisi Sistem Informasi Geografis (SIG) selalu berkembang, bertambah dan bervariasi. Hal ini dapat diketahui dengan banyaknya definisi SIG yang dinyatakan oleh para ahli. Selain itu, SIG merupakan suatu bidang kajian ilmu dan teknologi yang relatif baru, digunakan oleh berbagai bidang disiplin ilmu, dan berkembang dengan cepat. Berikut merupakan beberapa definisi SIG :

a. Sistem Informasi Geografis adalah sistem komputer yang digunakan untuk memasukan (capturing), menyimpan, memeriksa, mengintegrasikan, memanipulasi, menganalisa, dan menampilkan data yang berhubungan dengan posisi di permukaan bumi [6],

b. Sistem Informasi Geografis (SIG) adalah kombinasi perangkat keras dan perangkat lunak komputer yang memungkinkan untuk mengelola (manage), menganalisa, memetakan informasi spasial berikut data atributnya (data deskripsi) dengan akurasi kartografi [6],

c. Sistem Informasi Geografis (SIG) adalah sebuah sistem yang mampu mengumpulkan, mengelola, dan menganalisis data yang terikat dengan titik koordinat bumi (georeference),

d. Sistem Informasi Geografis (SIG) adalah sistem berbasis komputer yang digunakan untuk menyimpan,memanipulasi, dan menganalisis informasi geografi, Sistem Informasi Geografis (SIG) adalah kumpulan yang terorganisir dari perangkat keras komputer, perangkat lunak, data geografi, dan data personel yang didesain untuk memperoleh, menyimpan, memperbaiki,memanipulasi, menganalisa, dan menampilkan semua bentuk informasi yang bereferensi geografi (Badan Koordinasi Survey dan Pemetaan Nasional dalam Mustapa [7].

\section{METODOLOGI PENELITIAN}

3.1 Pada tahap analisa dilakukan dengan proses sebagai berikut :

3.1.1 DEM. Pada tahap ini dilakukan pembentukan DEM dari garis kontur yang terdapat pada peta RBI hingga menghasilkan suatu peta ketinggian wilayah dan peta kelerengan.

3.1.2 Citra TRMM Data citra TRMM 3B43 diekstrak menggunakan perangkat lunak software Orbit Viewer THOR (Tool for High Resolution Observation Review), untuk mendapatkan data curah hujan dan koordinat titik pengukuran hujan. Data hasil ekstraksi tersebut divalidasi dengan data curah hujan dari BMKG.

3.1.3 Overlay. Pada tahap ini dilakukan metode scoring untuk tiap kelas parameter genangan. Melalui metode ini, diberikan bobot dan skor untuk masing-masing kelas parameter Banjir. 
3.1.4 Analisa. Pada tahap analisa ini, dilakukan validasi peta bahaya banjir yang dihasilkan. Validasi dilakukan dengan menghitung tingkat korelasi antara daerah banjir tingkat tinggi pada beberapa daerah dengan data kejadian banjir tahun sebelumnya.

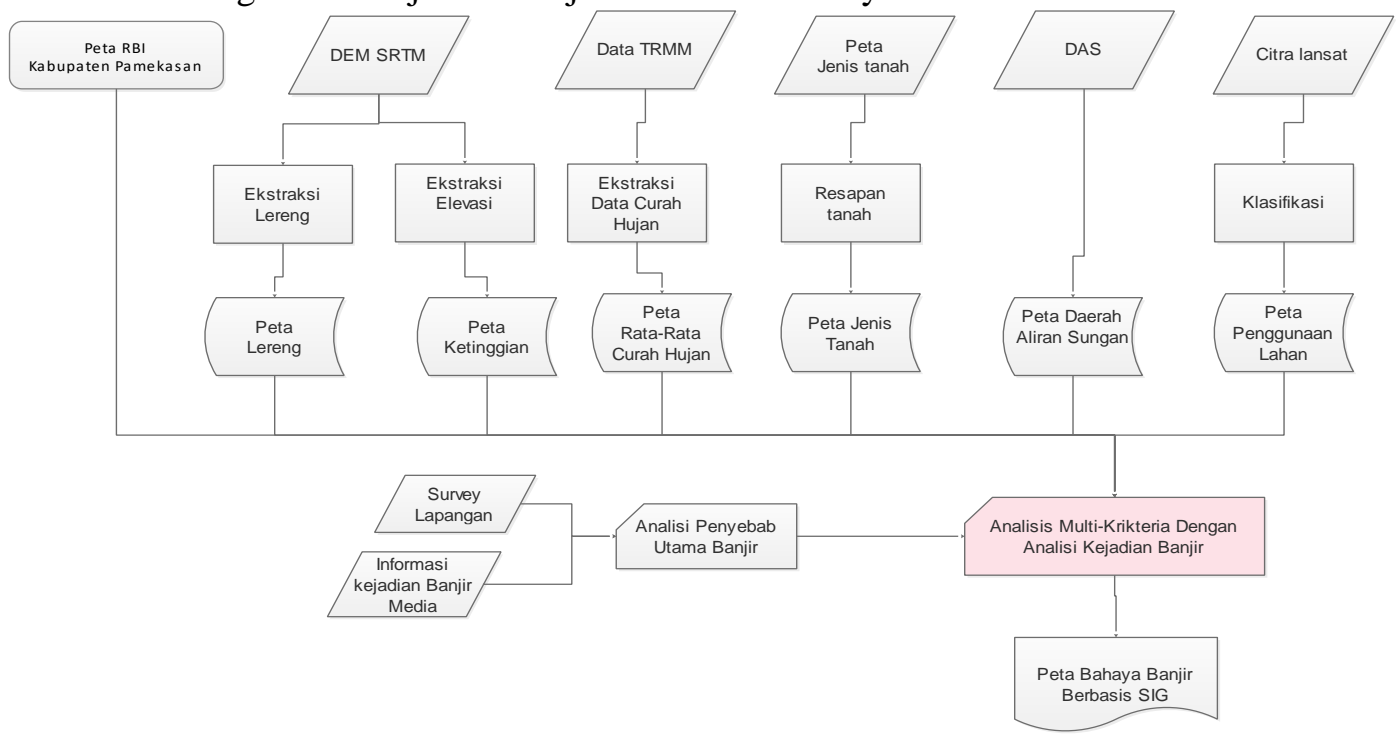

Gambar 2. Tahap Analisis Data

\section{HASIL DAN PEMBAHASAN}

\subsection{Grafik TRMM Dan Curah Hujan BMKG}

Grafik perbandingan menunjukkan perbedaan data curah hujan TRMM dengan data curah hujan Dinas Pengairan pada Tahun 2013, 2012, 2011 yang paling mencolok pada bulan Januari dengan selisih sekitar $193 \mathrm{~mm}$. Sedangkan yang memiliki nilai hampir sama terdapat pada bulan Juli dengan selisih sekitar $1,5 \mathrm{~mm}$. Perbedaan yang sangat mencolok tersebut dapat disebabkan oleh berbagai faktor. Salah satu faktor adalah kesalahan saat interpretasi kecerahan awan, hujan dari citra satelit TRMM. Faktor lainnya adalah kemungkinan adanya kecenderungan pola data curah hujan TRMM pada bulan Januari diintrepretasikan memiliki curah hujan yang tinggi. Adapun data yang diperoleh tidak selalu menunjukkan demikian.

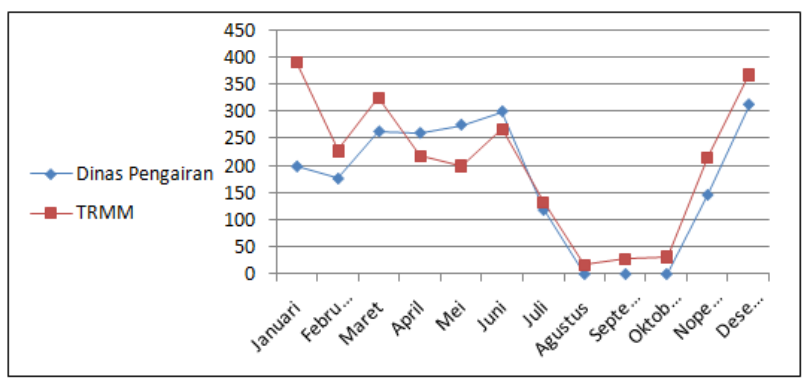

Gambar 3. Grafik Data Curah Hujan TRMM dan Data Curah Hujan

Dinas Pengairan Tahun 2013

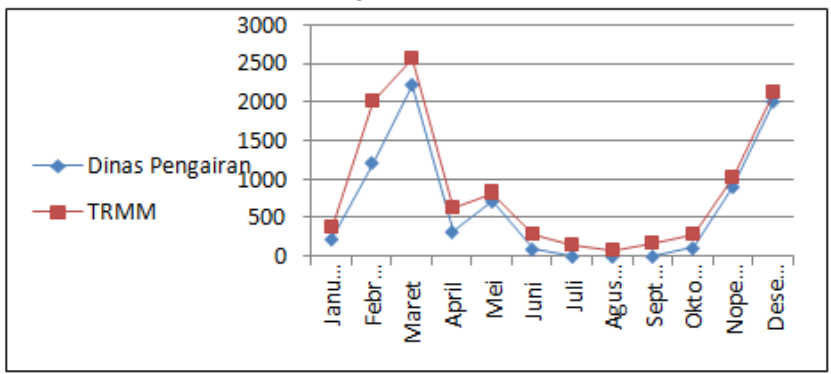

Gambar 4. Grafik Data Curah Hujan TRMM dan Data Curah Hujan Dinas Pengairan Tahun 2012 


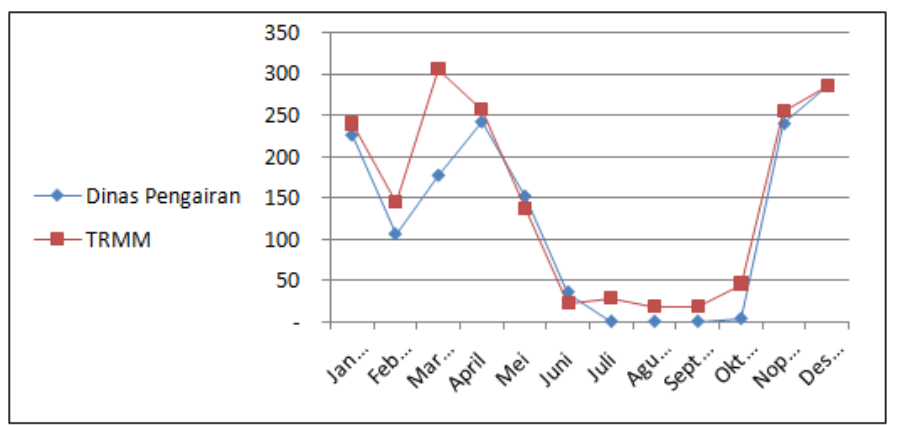

Gambar 5. Grafik Data Curah Hujan TRMM dan Data Curah Hujan Dinas Pengairan Tahun 2011

\subsection{Scatter Plot Curah Hujan TRMM dan BMKG}

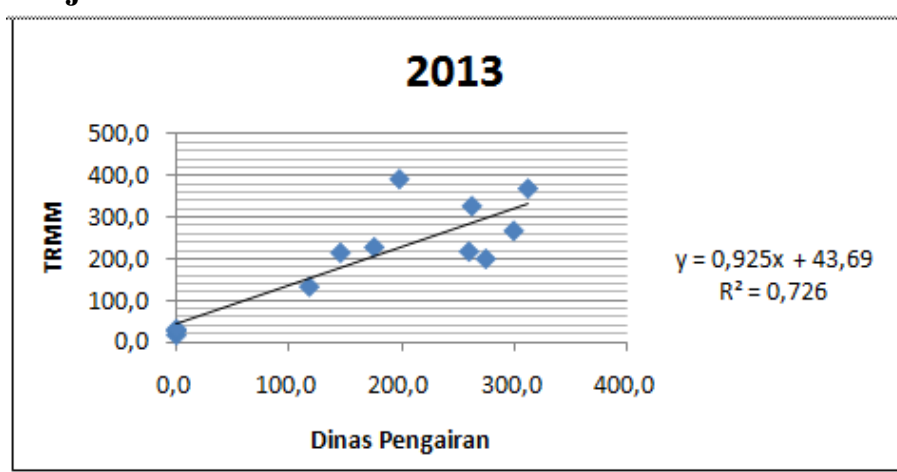

Gambar 6. Scatter Plot Curah Hujan TRMM dan Data Curah Hujan Dinas Pengairan Tahun 2013

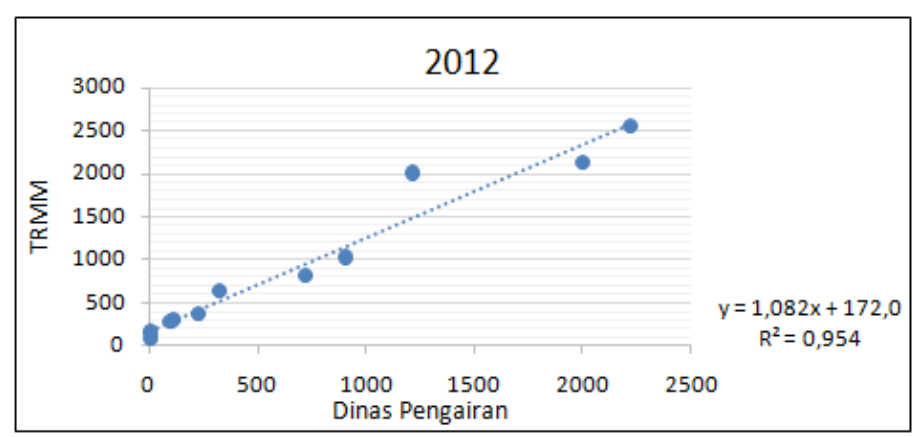

Gambar 7. Scatter Plot Curah Hujan TRMM dan Data Curah Hujan Dinas Pengairan Tahun 2012

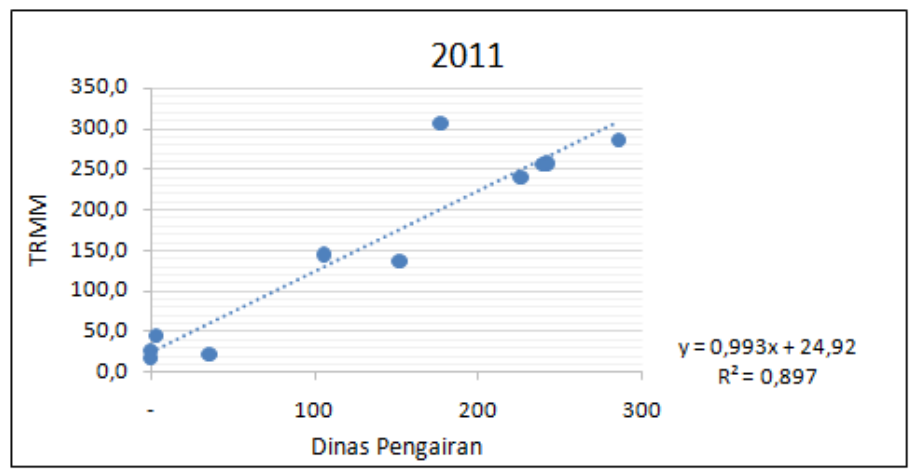

Gambar 8. Scatter Plot Curah Hujan TRMM dan Data Curah Hujan Dinas Pengairan Tahun 2011 


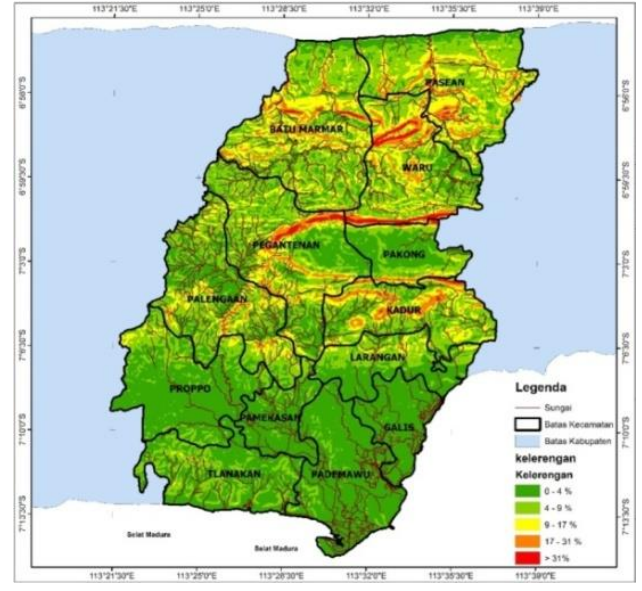

Peta Kelerengan Pamekasan

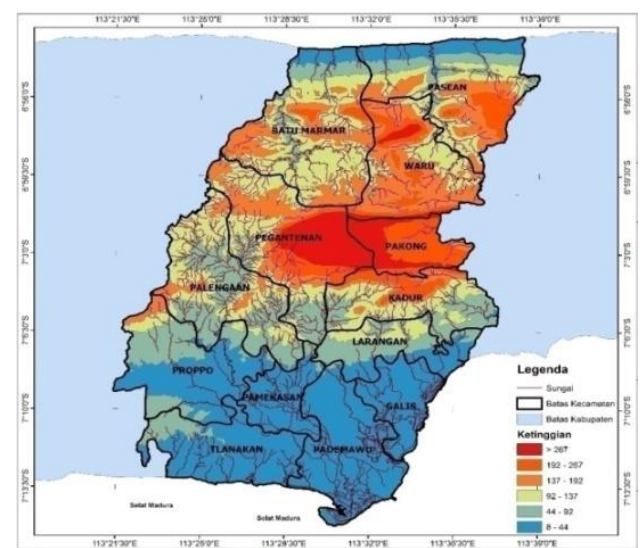

Peta Ketinggian Pamekasan

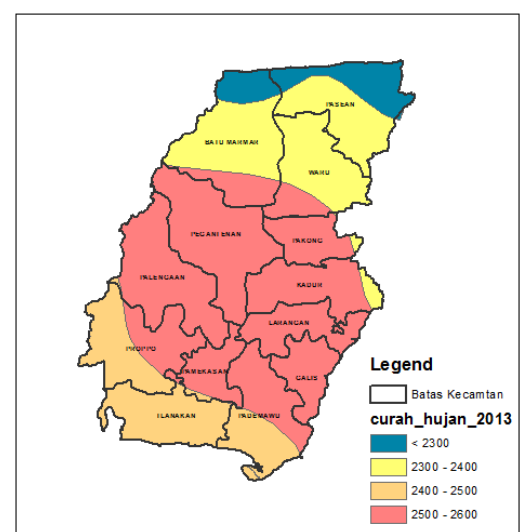

Peta Curah Hujan Pamekasan

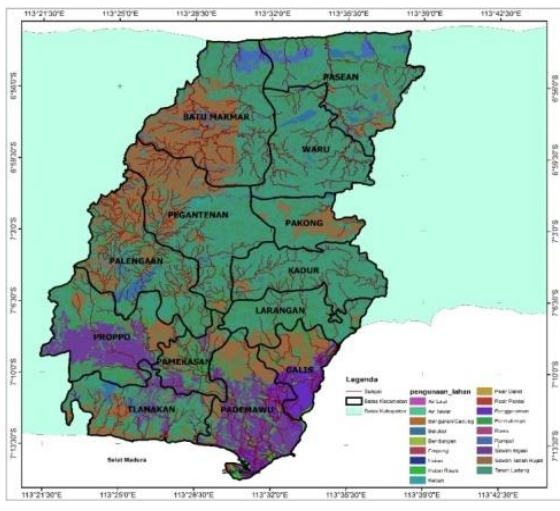

Peta Penggunaan Lahan Pamekasan

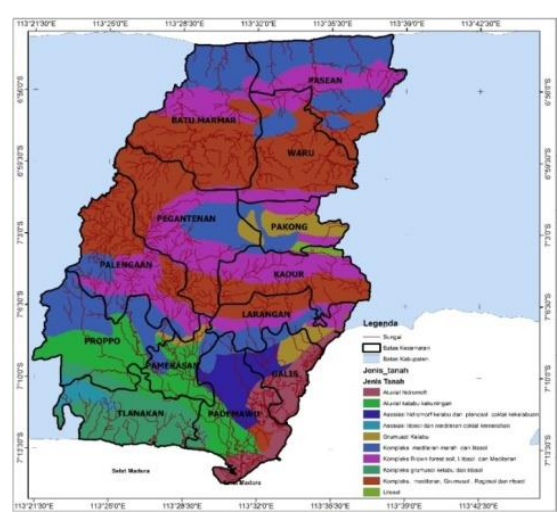

Peta Jenis Tanah Pamekasan

Gambar 9. Peta Data Varibel Meliputi Peta Kelerengan, Peta Ketinggian, Peta Curah Hujan, Peta Pengunaan Lahan, Peta Jenis Tanah.

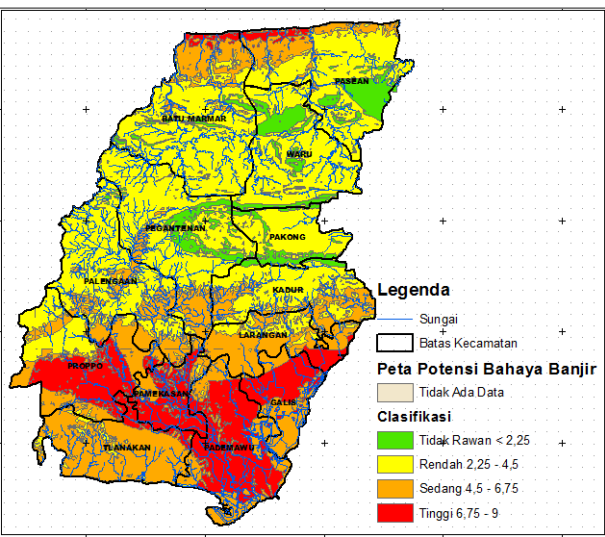

Gambar 10. Peta Hasil Rawan Bahaya Banjir

Gambar scatter plot menunjukkan persamaan garis regresi linier antara data curah hujan TRMM dengan Dinas Pengairan. Sesuai dengan yang telah tercantum pada Tinjauan Pustaka, dari persamaan tersebut, dapat dicari nilai korelasinya. Hasil perhitungan korelasi dengan menggunakan rumus umum maupun melalui persamaan regresi linier menunjukkan nilai $r_{x y=}{ }^{2} R^{2}$ Berdasarkan interpretasi koefisien korelasi oleh Guilford, dapat dikatakan bahwa nilai korelasi yang didapatkan di atas termasuk dalam 
korelasi sedang hingga korelasi tinggi. Daerah Pamekasan relatif datar dengan kemiringan $0-4 \%$ dan penggunaan yang paling banyak adalah permukiman mencapai 341240,721(Ha). Dan curah hujan pamekasan yang tinggi merupakan pemasok utama air yang menyebabkan Bahaya Banjir, Pada tahun 2013, curah hujan di Kabupaten Pamekasan cukup tinggi, dengan akumulasi rata-rata ,421 mm $\mathrm{mm} /$ tahun. Daerah tingkat tinggi sebagian besar berada pada keting gian $8-44,5$ meter. daerah berpotensi genangan tinggi didominasi oleh jenis tanah Alluvial Hidromorf.

\subsection{Peta Hasil Rawan Bahaya Banjir Pamekasan}

Gambar 10 merupakan daerah Potensi Genangan tinggi berada pada Kecamatan Pamekasan yaitu kelurahan Jelmak, Laden, Patemon, Cungcangcang, Partaker, Lawangan Daya, Konang. Daerahdaerah potensi genangan tinggi tersebut berada dekat dengan jaringan Sungai seperti Kali Topo, Kali Tarokan 1, Kali Tarokan 2, dan lain sebagainya. Dari data kejadian Banjir, area yang tergenang adalah area di Kecamatan kota. Hal ini cocok dengan Peta Daerah Potensi Genangan yang dihasilkan, dimana tampak pada gambar, area Kecamatan kota Pamekasan sebelah barat didominasi oleh area dengan tingkat potensi genangan yang tinggi. Kecamatan kota Kabupaten Pemekasan memang area yang sangat berpotensi tergenang karena memiliki wilayah yang relatif datar dan rendah, curah hujan yang tinggi, jenis tanah yang kurang mendukung terjadinya infiltrasi, serta merupakan area perkotaan yang padat penduduk sehingga kurang area resapan air.

\section{KESIMPULAN}

Dari hasil kesimpulan didapat analisa daerah potensi genangan dengan tingkat potensi tinggi berada pada daerah yang relatif datar dengan kemiringan $0-4 \%$ dan potensi genangan tinggi berada pada lahan dengan penggunaan yang paling banyak adalah permukiman mencapai 341240,721(Ha). Selain itu curah hujan yang tinggi merupakan pemasok utama air yang menyebabkan genangan, Pada tahun 2013, curah hujan di kabupaten Pamekasan cukup tinggi, dengan akumulasi rata-rata,421 $\mathrm{mm} \mathrm{mm} /$ tahun. Daerah potensi genangan tingkat tinggi sebagian besar berada pada ketinggian $8-44,5$ meter dan Jenis tanah juga merupakan penentu daerah potensi genangan, daerah berpotensi genangan tinggi didominasi oleh jenis tanah Alluvial Hidromorf. Daerah potensi genangan tinggi berada pada Kecamatan Pamekasan, Pademawu, Galis, Proppo.Daerah-daerah potensi genangan tinggi tersebut berada dekat dengan jaringan sungai Kali Topo, Kali Tarokan 1, Kali Tarokan 2, dan lain sebagainya. Penelitian Menunjukkan Tinggi 6,75 - 9 sedang 6,75 - 4,5 rendah 4,5 - 2,25 tidak rawan 2,25.

\section{DAFTAR PUSTAKA}

[1] Anonim, Dep PU. 1994. Teknologi Pengendalian Banjir di Indonesia. Direktorat Sungai, Ditjen Pengairan

[2] Fitrianto, D. 2009. Pengelolaan Lahan Daerah Aliran Sungai (DAS) Kemoning untuk Meminimalisasi Terjadinya Banjir Pada Daerah Hilir DAS Kemoning di Kabupaten Sampang Madura.

[3] Gunawan D, F Setyawan, Hariadi, T A Nuraini, U A Linarka \& Eko Heriyanto. 2010. Pemanfaatan Data Curah Hujan Satelit TRMM untuk Database Zona Prakiraan Musim. Laporan Akhir Program Insentif Riset Terapan, Kementerian Riset dan Teknologi.

[4] Hanafi, R. A. 2010. Pemetaan Geologi dengan Menggunakan Data Citra Alos di Daerah Pegunungan Selatan (Kabupaten Wonogiri - Jawa Tengah). Tugas Akhir. Surabaya: Program Studi Teknik Geomatika.

[5] Indarto dan Faisol A., 2009. Identifikasi dan Klasifikasi Peruntukan Lahan Menggunakan Citra Aster. Media Teknik Sipil, Volume IX. ISSN 1412-0976.

[6] Prahasta, E. 2001. Konsep-konsep Dasar Sistem Informasi Geografis. Penerbit Informatika. Bandung.

[7] Paryono, Petrus. (1994). Sistem Informasi Geografis. Edisi pertama. Andi Offset, Yogyakarta. 